\title{
Co-occurrence of shade-tolerant and light-adapted tree species in uneven-aged deciduous forests of southern Poland
}

\author{
Leszek Bartkowicz $^{1}$ (D) . Jarosław Paluch ${ }^{1}$
}

Received: 23 April 2018 / Revised: 25 October 2018 / Accepted: 30 October 2018 / Published online: 15 November 2018

(c) The Author(s) 2018

\begin{abstract}
This study tested the assumption that in mixed-species deciduous forests, shade tolerance determines the species' role in forming vertical structuring of the canopy layer and that persistence of light-adapted species in such forests is conditioned by the occurrence of larger disturbances and simple vertical structures. Several spatially explicit structural attributes were compared in the neighbourhood of eight tree species (Alnus glutinosa (L.) Gaertner, Carpinus betulus L., Fraxinus excelsior L., Pinus sylvestris L., Quercus robur L., Tilia cordata Miller, Ulmus laevis Pall., Ulmus minor Miller) with different shade tolerance growing in uneven-aged forests. The analysis indicated that although species light requirements were loosely related to the density and structural attributes of the stand patches in which the species occur, the light-adapted species tended to avoid close proximity to the shade-tolerant species. These results suggest that under-canopy trees of light-adapted or mid-tolerant species may survive successfully in heterogeneous canopies in the neighbourhoods of species with similar or higher light requirements. Hence, controlling the admixture of shade-tolerant species may be crucial for the persistence of light-adapted species in uneven-aged forests. The results also indicate that in the mixed-species deciduous forests of Central Europe, complex vertical structures arise not only in larger areas of several hundred square metres but also on small spatial scales corresponding to the projection area of canopy trees and suggest that maintaining species diversity in such forests may not require application of management systems based on extensive canopy openings.
\end{abstract}

Keywords Mixed-species forests $\cdot$ Patch mosaic $\cdot$ Spatial structure $\cdot$ Species diversity $\cdot$ Structured forest $\cdot$ Group selection system

\section{Introduction}

The significant changes in temperate zone forest ecosystems including the impoverishment of species composition and simplification of stand structures have resulted in a diminished ecosystem function (Bauhus et al. 2009). Yet the occurrence of structurally complex canopies made up of various tree species not only favours the biological productivity of forest ecosystems through complementary

Communicated by Miren del Rio.

Electronic supplementary material The online version of this article (https://doi.org/10.1007/s10342-018-1149-5) contains supplementary material, which is available to authorized users.

Leszek Bartkowicz

leszek.bartkowicz@urk.edu.pl

1 Department of Silviculture, Faculty of Forestry, University of Agriculture, Al. 29 Listopada 46, 31-425 Cracow, Poland utilization of resources but creates resource-rich habitats that enhance the biodiversity of canopy-dwelling organisms (Ishii et al. 2004). Structured multi-aged stands also exhibit greater resistance and resilience to disturbances, which is of increasing importance in times of rising uncertainty about future constraints and the existence of forest ecosystems (O'Hara and Ramage 2013). Nevertheless, compared to forests driven by natural dynamics, contemporary forest landscapes are characterized by a shortage of patches with several canopy layers, significant variation in tree size, and irregular gap size and distribution (Bauhus et al. 2009).

In the temperate zone, forest ecosystems with complex species composition are exemplified by mesophilous, deciduous forests associated with rich mineral soils. In general, these forests are built by different combinations of tree species from the genera Quercus, Acer, Fagus, Tilia, Fraxinus, Carpinus, Ulmus - and less frequently, Betula, Alnus, Juglans, Castanea, Liriodendron, Phellodendron, Carya and Magnolia - with the addition of conifers in the 
northern and mountain regions. The primary area occupied by such mixed-species forests, however, has been changed by farming, and preserved woodlands have been intensively exploited using the practice of even-aged management (Ishii et al. 2004). Nonetheless, in scattered temperate zone locations, some forest ecosystems have maintained their natural character and heterogeneous structure. Such forests have been studied in Central Europe ( $C$. betulus- $T$. cordataPicea abies-Acer platanoides-Q. robur forests) (Faliński 1988; Bobiec et al. 2000), in the Balkan region (Q. roburFraxinus angustifolia dominated riparian forests) (Bobinac 2000), in Manguria (Juglans mandshurica-Fraxinus mandshurica-Phellodendron amurense dominated forests and Pinus koraiensis-Tilia amurense-Quercus mongolicaFraxinus mandshurica forests) (Hao et al. 2007; Hui and Pommerening 2014), and in North America-principally in the northern hardwood region (Fagus grandifolia-Acer saccharum-Picea rubens-Abies balsamea-Betula alleghaniensis forests) (Leak 1996; Schwarz et al. 2001; Crow et al. 2002; Angers et al. 2005) and central hardwood region (Liriodendron tulipifera-Betula lutea-Castanea dentata-F. grandifolia-Acer saccharum forests) (Lorimer 1980).

The conservation of old-growth attributes in managed mixed-species deciduous forests may be accomplished by means of appropriate silvicultural practices. In east-central Maine, for example, the most advantageous approach for maintenance of close-to-nature structures and dynamic stand features was shown to be a single-tree selection system (Saunders and Wagner 2008). This management form also caused the least alteration to the understory plant species diversity (Duguid and Ashton 2013). The single-tree selection method has been regularly applied in deciduous forests in North America for the last few decades, not only in northern hardwood forests (Solomon and Gove 1999; Forget et al. 2007; Gronewold et al. 2010; Nolet et al. 2014) but also in mixed-species mesophytic forests located in the central hardwood region (Schuler 2004). In Europe, however, where continuous-cover forestry has the longest tradition (Schütz 2001), the single-tree selection or group selection methods are applied mostly in forests consisting of shade-tolerant or mid-tolerant coniferous species with little admixture of broadleaved species (Kolström 1993; Bachofen 1999) and only exceptionally in mixed or pure stands with predominant proportion of shade-tolerant Fagus sylvatica L. (Schütz 2002, 2006; Saniga 2010; Hessenmöller et al. 2018) or in coniferous stands of light-adapted species (Andrzejczyk 2006; Andrzejczyk and Żybura 2012).

One deeply held belief in traditional forestry management is that a tree species' light requirements is the most important factor influencing its potential to form and maintain complex vertical structures, which directly links a species' shade tolerance to its regeneration and recruitment strategy. Shadetolerant species are usually connected with successful natural regeneration in small gaps or under the canopy of light-adapted species, creating uneven-aged forest stands with several tree cohorts and the high spatial heterogeneity of tree distribution (Shugart 1984; Oliver and Larson 1996). Light-adapted species, however, need larger areas of significantly reduced canopy to establish younger tree cohorts, which generally involves stand structure simplification. This traditional view implies that in mixed-species forests with trees of different shade tolerance, complex vertical structure is a transitive attribute resulting from the periodical co-existence of light-adapted species in the upper canopy and shade-tolerant species in the middle or lower canopy layer (Connel and Slatyer 1977; Whitmore 1989; Yamamoto 2000). Maintaining this species diversity requires extensive disturbances and larger areas with a simple vertical structure and smaller canopy density for light-adapted species to advance into the canopy layer (Whitmore 1989). Yet an alternative mechanism may be proposed based on variable shade tolerance through a species life-history (Fahey and Lorimer 2013, 2014). This concept assumes that young trees of less shade-tolerant species are sufficiently adapted to successfully develop in larger gaps created by small groups of dead canopy trees; that is, under the regime of small-scale disturbances (Lorimer 1980). Medium-to-large-scale disturbances, although favourable, would not be absolutely essential for the persistence of the populations of the less shade-tolerant species.

The objective of the study was to test the assumption that in mixed-species deciduous forests shade tolerance determines the species' role in forming vertical structuring of the canopy layer and that local neighbourhoods of light-adapted and shade-tolerant species considerably differ in terms of vertical structure and canopy density. Because depending on position in the canopy, trees of the same species may differently contribute to the structural complexity of their surroundings, three hypotheses were postulated based on the traditional view of the co-occurrence pattern of species with different light requirements: (H1) in the case of trees in the upper canopy stratum, the structural complexity is higher in the surroundings of lightadapted than in those of shade-tolerant species, (H2) in the case of trees in the lower canopy stratum, the structural complexity is higher in the surroundings of shade-tolerant than in those of light-adapted species, and (H3) in the case of trees in the lower and middle canopy strata, species' increasing light requirements are negatively correlated with local stand density.

\section{Methods}

\section{Study area}

The study area, located in southern Poland and confined by the geographic coordinates $50.007^{\circ} \mathrm{N}$ and $50.112^{\circ} \mathrm{N}$ and $20.352^{\circ} \mathrm{E}$ and $20.425^{\circ} \mathrm{E}$ (Table 1), is a lowland flat 
area (185-220 $\mathrm{m}$ a.s.1.) situated in the fork of the upper Vistula river and the Vistula's southern branch, the river Raba. The parent material consists of interspersing holocene alluvial deposits and pleistocene fluvioglacial and bottom moraine sediments on which Cambisols, Gleysols, Stagnosols, and Phaeozems have developed (IUSS Working Group WRB 2015). The climatic conditions are typical for a nemoral zone with an increased influence of continental characteristics. The average annual temperature is $8{ }^{\circ} \mathrm{C}$ with an annual precipitation of $650 \mathrm{~mm}, 60 \%$ of which occurs between May and October. The growing period with daily temperatures above $5{ }^{\circ} \mathrm{C}$ is about 230 days (Suliński 1981).

The entire study region is localized within a floodplain terrace of the Vistula and Raba rivers. Originally, the flooding episodes occurred spontaneously, but high overbank flows resulting in inundation of the entire alluvial area happened relatively rare. In the majority of cases, the lower flows discharged in floodplain scrolls and numerous ground depressions (Bzowski 1973). In the mid-nineteenth century, however, a provisory embankment was constructed that considerably reduced flood water penetration. The erection of a contemporary flood bank system, by the beginning of the twentieth century, cuts off the forest ecosystems from the periodical flooding. Since then, overflows have been able to break into forested land only in the case of bank interruption, which in fact happened in the 3rd and 7th decades of the twentieth century (Bzowski 1973). Nevertheless, despite this drastic reduction in alluvial processes, after heavy rains, extensive areas of the forests have been subject to inundation because of rapidly increasing ground water level and the impossibility of draining the terrain through a ditch system whose endings are below the river flow level. In addition,

Table 1 Location and site characteristics of the sample plots

\begin{tabular}{|c|c|c|c|c|c|c|c|}
\hline Plot no. & Location & Soil $^{1}$ & Forest association $^{2}$ & $\begin{array}{l}N \\
\left(\mathrm{ha}^{-1}\right)\end{array}$ & $\begin{array}{l}\text { Basal area } \\
\left(\mathrm{m}^{2} \mathrm{ha}^{-1}\right)\end{array}$ & $\begin{array}{l}\text { Volume } \\
\left(\mathrm{m}^{3} \mathrm{ha}^{-1}\right)\end{array}$ & $\begin{array}{l}\text { Species composition }{ }^{3} \\
\text { (\% of basal area) }\end{array}$ \\
\hline 1. & $50.053^{\circ} \mathrm{N} 20.366^{\circ} \mathrm{E}$ & Gleysol & $\begin{array}{c}\text { Oak-hornbeam } \\
\text { poor variant }\end{array}$ & 536 & 32.4 & 335 & $Q 53-P 28-C 17-O 2$ \\
\hline 2. & $50.093^{\circ} \mathrm{N} 20.364^{\circ} \mathrm{E}$ & Stagnosol & Oak-hornbeam & 450 & 35.5 & 471 & $Q 41-P 25-T 21-C 13$ \\
\hline 3. & $50.096^{\circ} \mathrm{N} 20.378^{\circ} \mathrm{E}$ & Mollic Cambisol & Oak-hornbeam & 422 & 31.7 & 395 & $T 39-Q 26-P 18-C 17$ \\
\hline 4. & $50.088^{\circ} \mathrm{N} 20.364^{\circ} \mathrm{E}$ & Cambisol & Oak-hornbeam & 448 & 28.9 & 358 & $T 34-Q 33-C 30-P 3$ \\
\hline 5. & $50.083^{\circ} \mathrm{N} 20.389^{\circ} \mathrm{E}$ & Stagnosol & $\begin{array}{l}\text { Oak-hornbeam } \\
\text { wet variant }\end{array}$ & 236 & 32.6 & 488 & $Q 54-C 30-T 16$ \\
\hline 6. & $50.086^{\circ} \mathrm{N} 20.388^{\circ} \mathrm{E}$ & Stagnosol & $\begin{array}{l}\text { Oak-hornbeam } \\
\text { wet variant }\end{array}$ & 248 & 30.4 & 430 & $Q 48-T 34-C 18$ \\
\hline 7. & $50.089^{\circ} \mathrm{N} 20.356^{\circ} \mathrm{E}$ & Mollic Cambisol & $\begin{array}{l}\text { Oak-hornbeam } \\
\text { wet variant }\end{array}$ & 344 & 36.8 & 473 & $Q 33-T 27-C 22-A 18$ \\
\hline 8. & $50.007^{\circ} \mathrm{N} 20.418^{\circ} \mathrm{E}$ & Stagnosol & $\begin{array}{l}\text { Oak-hornbeam } \\
\text { wet variant }\end{array}$ & 253 & 25.6 & 345 & $Q 87-T 9-C 3-A 1$ \\
\hline 9. & $50.112^{\circ} \mathrm{N} 20.425^{\circ} \mathrm{E}$ & Stagnosol & $\begin{array}{l}\text { Oak-hornbeam } \\
\text { wet variant }\end{array}$ & 567 & 27.9 & 302 & $Q 65-T 17-C 9-F 7-O 2$ \\
\hline 10. & $50.110^{\circ} \mathrm{N} 20.373^{\circ} \mathrm{E}$ & Mollic Cambisol & $\begin{array}{l}\text { Oak-hornbeam } \\
\text { wet variant }\end{array}$ & 500 & 35.6 & 527 & $F 46-Q 34-C 17-P 3$ \\
\hline 11. & $50.101^{\circ} \mathrm{N} 20.355^{\circ} \mathrm{E}$ & Mollic Cambisol & Oak-hornbeam/riparian & 436 & 32.4 & 471 & $Q 42-F 39-T 12-C 4-O 3$ \\
\hline 12. & $50.109^{\circ} \mathrm{N} 20.352^{\circ} \mathrm{E}$ & Mollic Cambisol & Oak-hornbeam/riparian & 373 & 30.6 & 477 & $Q 48-F 37-A 7-O 5-U l 3$ \\
\hline 13. & $50.064^{\circ} \mathrm{N} 20.375^{\circ} \mathrm{E}$ & Gleysol & Riparian & 317 & 38.1 & 497 & Q61-A14-C14-Ul6-O4-P1 \\
\hline 14. & $50.103^{\circ} \mathrm{N} 20.381^{\circ} \mathrm{E}$ & Stagnosol & Riparian & 286 & 35.8 & 518 & $Q 57-U l 22-A 16-C 4-T 1$ \\
\hline 15. & $50.079^{\circ} \mathrm{N} 20.366^{\circ} \mathrm{E}$ & Stagnosol & Riparian & 344 & 35.3 & 464 & A36-Ul33-Q19-C10-Um2 \\
\hline 16. & $50.079^{\circ} \mathrm{N} 20.375^{\circ} \mathrm{E}$ & Stagnosol & Riparian & 278 & 41.4 & 577 & $A 46-Q 22-U l 20-C 9-T 2-U m 1$ \\
\hline 17. & $50.082^{\circ} \mathrm{N} 20.369^{\circ} \mathrm{E}$ & Stagnosol & Riparian wet variant & 583 & 35.4 & 406 & A52-Ul16-Q11-T8-C5-Um5-O3 \\
\hline 18. & $50.008^{\circ} \mathrm{N} 20.417^{\circ} \mathrm{E}$ & Stagnosol & Riparian wet variant & 305 & 33.5 & 464 & $Q 72-A 25-C 2-O 1$ \\
\hline
\end{tabular}

\footnotetext{
${ }^{1}$ According to IUSS Working Group WRB (2015)

${ }^{2}$ According to Matuszkiewicz (2001): oak-hornbeam-poor variant (Tilio-Carpinetum caricetosum brizoides), oak-hornbeam (Tilio-Carpinetum typicum), oak-hornbeam - wet variant (Tilio-Carpinetum stachyetosum), riparian forest (Ficario-Ulmetum minoris), riparian-wet variant (Fraxino-Alnetum)

${ }^{3}$ Species: A-Alnus glutinosa (L.) Gaertner, $Q$-Quercus robur L., F-Fraxinus excelsior L., P-Pinus sylvestris L., T-Tilia cordata Miller, C-Carpinus betulus L., Ul-Ulmus laevis Pall., Um-Ulmus minor Miller, $O$ - others
} 
during spring, snowmelt ground waters tend to stagnate in terrain depressions on clayey soils (Bzowski 1973).

The forest area in which the research plots were located has been known since the second half of the fourteenth century as the Niepołomice Forest, which until the mid-eighteenth century was partially protected as a royal hunting area. In the modern era, a dense net of floodplain scrolls, old river beds, and oxbow lakes (Pawlik 1913) — as well as the forest's increasing importance as the "green lungs" for the urban industrial agglomeration of Kraków-has fostered the preservation of its natural character (Dziewolski 1976). Today, this area has maintained numerous fragments of semi-natural old-growth stands, which have not been subjected to intensive management. Not only was harvesting delayed until the majority of the canopy trees were 180 years old, but preharvesting treatments were usually limited to the cutting of dying or damaged trees. In addition, artificial planting was not introduced into the region until the 1930s (Dziewolski 1976), so the dynamics of the stands studied were predominantly influenced by natural processes. Nonetheless, pasturing, foraging, and raking of the forest floor by the local population until the mid-twentieth century might also have affected species composition and the structural traits of the stands in the region.

One remarkable feature of the stands studied is the occurrence of several species with varied light requirements in different stand layers, as well as the vertical differentiation of the stand structure at small spatial scales. These mixedspecies forests variously consist of the following species, ranked by their descending proportion in the bulk volume of the stands: oak $Q$. robur L., alder A. glutinosa (L.) Gaertner, hornbeam $C$. betulus L., lime T. cordata Miller, ash F. excelsior L., European white elm U. laevis Pall., pine P. sylvestris L. (the only conifer species), and field elm U. minor Miller. The stands growing on less fertile sites consist largely of oak, hornbeam, and pines, whereas on more eutrophic sites, the proportion of pine gradually diminishes, and oak, hornbeam, and lime predominate. In areas with higher soil moisture, the proportions of alder, elm, and ash increase at the expense of hornbeam and lime, but the proportion of oak remains constant.

\section{Study plots and field measurements}

The study was conducted on 18 square plots, each with an area of 0.64 ha (Table 1). The criteria for selecting the sample plots were a complex vertical stand structure (Supplementary material, Fig. S1), diversified species composition, the occurrence of tree species of different light requirements in different stand strata (Supplementary material, Table 1), and an absence of tree stumps cut in the last 20 years. The field measurements, taken between 2010 and 2012 (as a one-time survey on each plot), comprised stem coordinates (accurate to $0.5 \mathrm{~m}$ ), tree heights and diameters $(d b h)$, and crown radii determined in the four cardinal compass directions $(\mathrm{N}, \mathrm{E}, \mathrm{S}, \mathrm{W})$ for all live trees of $d b h \geq 7.0 \mathrm{~cm}$. The crown radii were measured by a two-person team that first determined the cardinal directions using a compass and then projected the crown margins onto them using a spirit level. Both the crown radii and the tree heights were determined in the leafless period.

The stem numbers, basal areas, and stand volumes on the sample plots are given in Table 1 . The $d b h$ distributions represent types of multi-modal, negative exponential, or rotated sigmoid distributions (Supplementary material, Fig. S2). The stands were uneven-aged with age variationestimated between 2000 and 2015 by counting the rings on stumps of the largest and smallest trees in the adjacent harvested stands - greater than 150 years (data not published/L. Bartkowicz, pers. comm.). Based on variation in diameters and morphological features of the single trees, it may be assumed that in addition to multi-aged populations of the shade-tolerant species hornbeam and lime, some plots contained multi-aged populations of light-adapted oak (Plot Nos. 1, 8, 9, 18) and alder (Plot Nos. 17 and 18) and at least two generations of pine (Plot No. 1) and ash (Plot Nos. 11 and 12, Supplementary material, Fig. S2).

\section{Characteristics of local species diversity and local stand density}

To express local species diversity, a Shannon index based on species frequencies (i.e. proportion in stem number) was calculated for all trees of $d b h \geq 7.0 \mathrm{~cm}$ growing within $a<8.9 \mathrm{~m}$ radius from (and including) the subject tree.

The local stand density was expressed as the cumulated basal area of all trees of $d b h \geq 7.0 \mathrm{~cm}$ growing within $a<8.9 \mathrm{~m}$ radius (henceforth, BA), with the basal area of the subject tree (for which the index was calculated) excluded from the calculations. An 8.9 m radius patch size corresponded to the maximal crown width of canopy trees and was calculated as an average of the maximal crown radii determined for trees of $d b h>50 \mathrm{~cm}$. Because the species occurring on the sample plots differed considerably in foliage density, the cumulated basal area was also weighted by the relative leaf area index of the respective species (henceforth, $\mathrm{BA}_{\mathrm{LAI}}$ ). Based on the literature (Eliaš et al. 1989; Stenberg et al. 1994; Čermak 1998; Soudani et al. 2002; Šramek and Čermak 2012), the following species-specific LAI indices were assumed: pine 1.5, alder 2.5, oak and ash 3.0, field and white elm 4.0, lime 5.0, and hornbeam 5.5. Considering hornbeam as the species with the highest LAI value in the data set, the following weights were used to calculate the $\mathrm{BA}_{\mathrm{LAI}}$ index: pine 0.27 ; alder 0.45 ; oak and ash 0.55 ; field elm, white elm, sycamore 0.73 ; lime (and other unlisted shade-tolerant species) 0.91 ; hornbeam 1.0; 
Table 2 Spatial distribution patterns of trees from different size classes and shade tolerance groups characterized using a univariate Ripley's K-function

\begin{tabular}{|c|c|c|c|c|c|c|c|c|c|}
\hline \multirow[t]{2}{*}{ Plot no. } & \multicolumn{3}{|c|}{$\begin{array}{l}\text { Large-diameter trees } \\
(d b h \geq 50 \mathrm{~cm})\end{array}$} & \multicolumn{3}{|c|}{$\begin{array}{l}\text { Medium-diameter trees } \\
(20 \mathrm{~cm} \geq d b h<50 \mathrm{~cm})\end{array}$} & \multicolumn{3}{|c|}{$\begin{array}{l}\text { Small-diameter trees } \\
(7 \mathrm{~cm} \geq d b h<20 \mathrm{~cm})\end{array}$} \\
\hline & Intolerant & Mid-tolerant & Tolerant & Intolerant & Mid-tolerant & Tolerant & Intolerant & Mid-tolerant & Tolerant \\
\hline 1. & 0 & - & - & $\mathrm{A}>4$ & - & $\mathrm{R}<5$ & $A>3$ & - & $\mathrm{A}>0$ \\
\hline 2. & $\mathrm{R}<11$ & - & $\mathrm{R}<8$ & $\mathrm{R}<3 \mathrm{~A}>14$ & - & $\mathrm{R}<10$ & - & - & 0 \\
\hline 3. & $\mathrm{R}<38>\mathrm{R}<15$ & - & $\mathrm{R}<3$ & - & - & $\mathrm{A}>11$ & - & - & $A>6$ \\
\hline 4. & $\mathrm{R}<7$ & - & $\mathrm{R}<7$ & - & - & 0 & - & - & $A>2$ \\
\hline 5. & $\mathrm{R}<3$ & - & 0 & - & - & $\mathrm{R}<8$ & - & - & $\mathrm{R}<10$ \\
\hline 6. & $\mathrm{R}<4$ & & $\mathrm{R}<10$ & - & - & $\mathrm{R}<9$ & - & - & $A>5$ \\
\hline 7. & $\mathrm{R}<3$ & - & $\mathrm{R}<4$ & $\mathrm{R}<7 \mathrm{~A}>13$ & - & 0 & - & - & $\mathrm{A}>4$ \\
\hline 8. & $\mathrm{R}<7$ & - & - & $7>A<14$ & - & $\mathrm{A}<15$ & 0 & - & - \\
\hline 9. & $\mathrm{R}<9$ & - & - & $\mathrm{A}>0$ & $\mathrm{R}<2$ & $9>A<5$ & $\mathrm{~A}>2$ & $A>2$ & $A>2$ \\
\hline 10. & $\mathrm{~A}>18$ & $\mathrm{R}<4$ & - & 0 & - & $\mathrm{A}>4$ & - & $\mathrm{A}>0$ & $A>2$ \\
\hline 11. & $\mathrm{R}<2$ & $\mathrm{R}<7$ & - & $\mathrm{R}<3$ & $\mathrm{R}<2 \mathrm{~A}>13$ & $\mathrm{R}<8$ & - & $A>3$ & $A>8$ \\
\hline 12. & $\mathrm{R}<7$ & 0 & - & $\mathrm{R}<6$ & $\mathrm{R}<6$ & - & - & $A>2$ & - \\
\hline 13. & $\mathrm{R}<8$ & - & - & 0 & - & $\mathrm{R}<6$ & - & $\mathrm{R}<4$ & $\mathrm{~A}>4$ \\
\hline 14. & $A>3$ & $A>6$ & - & $A>3$ & 0 & $\mathrm{R}<6$ & - & $A>3$ & $A>6$ \\
\hline 15. & $\mathrm{R}<7$ & 0 & - & $\mathrm{A}>7$ & 0 & 0 & - & $A>3$ & 0 \\
\hline 16. & $\mathrm{R}<5$ & $\mathrm{R}<48>\mathrm{A}<12$ & - & 0 & $\mathrm{R}<5$ & 0 & - & $\mathrm{A}<14$ & $A<6$ \\
\hline 17. & $\mathrm{R}<10$ & $\mathrm{R}<7$ & - & $\mathrm{A}>0$ & $\mathrm{R}<2$ & $\mathrm{~A}>12$ & - & $\mathrm{A}>2$ & $\mathrm{~A}>0$ \\
\hline 18. & 0 & - & - & $\mathrm{R}<39>\mathrm{A}<13$ & - & - & 0 & - & - \\
\hline
\end{tabular}

$\mathrm{A}=$ aggregated, $\mathrm{R}=$ regular, $0=$ random patterns. The numbers after the symbols $\mathrm{A} / \mathrm{R} / 0$ indicate spatial ranges (in $\mathrm{m}$ ) of significant deviations towards aggregated or regular patterns (two-sided $\alpha=0.05$ ). The calculations were performed if the number of trees in a given group exceeded 10 per sample plot. Shade tolerance groups: light-adapted (intolerant) species: P. sylvestris L., Q. robur L., A. glutinosa (L.) Gaertner, mid-tolerant species: F. excelsior L., U. laevis Pall., U. minor Miller, tolerant species: T. cordata Miller, C. betulus L.

and other unlisted light-adapted species 0.5 . To avoid border effects, the BA and $\mathrm{BA}_{\mathrm{LAI}}$ indices were calculated only for the trees growing at a distance greater than $8.9 \mathrm{~m}$ from the nearest study plot border (i.e. for 2674 trees).

The local density characteristics were then extended using numerical crown projection indices (CP) calculated for any given tree as the ratio of its free crown projection area (i.e. the area of its horizontal crown projection not overlapped by other tree crowns) to its total horizontal crown projection area. The crown projection index values thus lie between 0 and 1 . In the case of trees growing in the sample plot border zone, only the proportion of crown projected within the plot was considered. For large-diameter trees, the $\mathrm{CP}_{\mathrm{FFB}}$ index was determined as the crown projection fraction free from below (i.e. not overlapped by smaller neighbours' crown projections); for small-diameter trees, the $\mathrm{CP}_{\mathrm{FFA}}$ index was computed as the crown projection fraction free from above (i.e. not overlapped by taller neighbours' crown projections); for medium-diameter trees, both the $\mathrm{CP}_{\mathrm{FFB}}$ and $\mathrm{CP}_{\mathrm{FFA}}$ indices were calculated. The crown projection indices directly link a species' light requirements to its role in building the forest canopy, and more precisely, to the ability of canopy trees to eliminate smaller trees growing beneath the canopy $\left(\mathrm{CP}_{\mathrm{FFB}}\right.$ index $)$ or young trees to grow in the shelter of taller trees $\left(\mathrm{CP}_{\mathrm{FFA}}\right.$ index). Thus, a higher
$\mathrm{CP}_{\mathrm{FFB}}$ value determined for a given species is assumed to be associated with increased light attenuation in that species' tree crowns and with an increased shading effect. In the case of $\mathrm{CP}_{\mathrm{FFA}}$, this relation is reversed: increasing index values are assumedly associated with decreasing shade tolerance.

\section{Characteristics of local vertical differentiation}

Local differentiation in vertical structure was determined using the Staudhammer and LeMay (2001) DIFF index:

DIFF $=\left\{\begin{array}{l}\frac{S_{x}^{2}}{S_{U}^{2}} \Leftrightarrow S_{x}^{2} \leq S_{U}^{2} \\ 1-\frac{S_{x}^{2}-S_{U}^{2}}{S_{\max ^{-S_{U}^{2}}}^{2}} \Leftrightarrow S_{x}^{2}>S_{U}^{2},\end{array}\right.$

where $S_{x}^{2}$ is the empirical variance for tree heights, $S_{U}^{2}=\left(H_{\max }-H_{\min }\right)^{2} / 12$ is the variance of a uniform distribution dependent on maximal and minimal tree heights $H_{\max }$ and $H_{\min }$, and $S_{\max }^{2}=\left(H_{\max }-H_{\min }\right)^{2} / 4$ is the maximal variance of a bimodal distribution dependent on maximal and minimal tree heights. The calculation of the empirical variance $S_{x}^{2}$ considered all trees of $d b h \geq 7.0 \mathrm{~cm}$ growing within a $8.9 \mathrm{~m}$ radius from the subject tree as well as the subject 
tree itself. The DIFF index values range between 0 and 1 , with a low index value indicating little height differentiation and a one-layered vertical structure, and a high index value indicating similarity to a uniform distribution with an equal proportion of trees in the entire height interval between $H_{\text {min }}$ and $H_{\max }$. Unlike standard dispersion measures, the DIFF index assumes higher values for uniform distributions (i.e. multi-strata structures) than for bimodal distributions (twostrata structures). For enhanced comparability of results, the parameters $H_{\min }(7.3 \mathrm{~m})$ and $H_{\max }(34.4 \mathrm{~m})$-and thus also the theoretical variances $S_{U}^{2}$ and $S_{\max }^{2}$-were kept constant. These $H_{\min }$ and $H_{\max }$ values were derived from the data set as the 0.05 and 0.95 percentiles for small-diameter and large-diameter trees, respectively. For subject trees growing in the sample plot border zones, the edge effects were assumed not to significantly affect the values of this nonadditive index because the differentiation in vertical structure within the border zone and outside the sample plots was similar and outcome bias would equally burden the results for all species.

\section{Inter-species comparisons}

The analysis included a total of 4214 trees of eight species whose light requirements are ranked in the literature from most light-adapted to more shade-tolerant species: pine $>$ a lder $>$ oak $>$ ash $>$ field elm $>$ white elm $>$ lime $>$ hornbeam (Burschel and Huss 1997; Jaworski 2011). Another 14 species were present on the study plots, but only in small numbers, so although used in calculating the local density and structural variability indices, they were not considered in the inter-species comparisons. As postulated in the hypotheses $\mathrm{H} 1-\mathrm{H} 3$, depending on size and position in the canopy, trees of the same species may differently contribute to the structural complexity of their surroundings. Hence, separate analyses were conducted for large-diameter trees $(d b h \geq 50 \mathrm{~cm})$, medium-diameter trees $(20 \mathrm{~cm} \leq d b h<50 \mathrm{~cm})$, and smalldiameter trees $(7 \mathrm{~cm} \leq d b h<20 \mathrm{~cm})$. The proportion of species in the large-, medium-, and small-diameter tree classes are provided in Supplementary material (Table S1). The chosen diameter classes well reflected canopy stratification in the single stands: in the classes of small- and mediumdiameter trees, the mean tree heights were between 32 and $54 \%$ and between 68 and $82 \%$ of the mean height of the 100 highest trees per ha, respectively. In addition, this division resulted in similar values of the mean diameter and mean height for the eight species included in the analysis: in relation to the overall means, the differences were between -12 and $+15 \%$ (depending on the diameter class). Because of skewed distributions, the statistical significance of the between-species differences in the values of the Shannon's, $\mathrm{BA}, \mathrm{BA}_{\mathrm{LAI}}, \mathrm{CP}_{\mathrm{FFA}}, \mathrm{CP}_{\mathrm{FFB}}$, and DIFF indices pooled from all the sample plots was tested using two-sided permutation tests (1000 random permutations) (Efron and Tibshirani 1993, pp. 202-219), and a Holm-Bonferroni correction was applied to multiple comparisons, with a desired overall alpha level of 0.05 .

\section{Analysis of spatial distribution patterns}

Because the species were frequently represented on the sample plots by few individuals, the spatial analyses were conducted for groups of species dependent on their light requirements (light adapted: pine, oak and alder; mid-tolerant: ash and elms; shade-tolerant: lime and hornbeam). The spatial distribution patterns of trees from different size classes (i.e. small-, medium-, and large-diameter trees) and shade tolerance groups were characterized using a univariate Ripley's K-function, whereas spatial dependence of their distribution using a bivariate Ripley's K-function (Diggle 1983). In the latter case, the null hypothesis was that the locations of types 1 and 2 resulted from two a priori independent spatial point processes, while the alternative hypotheses posited negative dependence (between-types aggregation) or positive dependence (between-type repulsion) (Goreaud and Pélissier 2003). A radius of $20 \mathrm{~m}$ and an interval of $1 \mathrm{~m}$ were assumed as a maximal distance and a minimal interval of analysis, respectively. To obtain pointwise critical envelopes at the conventional 95\% level for tests of the hypothesis of complete spatial randomness (for the univariate analyses) or spatial independence (for the bivariate analyses), Monte Carlo simulations (1000 iterations) were carried out (Diggle 1983). In the bivariate analyses, these simulations employed a random shifts method to preserve the patterns' spatial properties.

\section{Results}

\section{Large-diameter trees}

The large-diameter trees were growing in species-diversified surroundings, and in the patches with an $8.9 \mathrm{~m}$ radius (corresponding to the maximal crown width of the canopy trees), an average of 3-4 species was present. At this spatial scale, the proportion of co-existing light-adapted species (i.e. pines, alders, and oaks) was highest in the surroundings of large-diameter pines, alders, oaks, and elms, and lowest around limes and hornbeams (Fig. 1a). The highest diversity measured by the Shannon index was in the neighbourhood of elm, pine, and alder; and the lowest, around limes and hornbeams (Fig. 2a).

The surroundings of different species did not differ significantly in BA (Fig. 3a). However, the analysis that corrected for species-specific LAI indicated significantly lower values of $\mathrm{BA}_{\mathrm{LAI}}$ in the neighbourhood of shade-tolerant 
hornbeams than around other species (Fig. 4a). As indicated by the $\mathrm{CP}_{\mathrm{FFB}}$ index (Fig. 5a), small trees spread their crowns in the under-crown zones of shade-tolerant trees less frequently than in the under-crown zones of their light-adapted neighbours. Compared to the ecological scale of shade tolerance derived from the literature (pine $>$ alder $>$ oak $>$ ash $>$ elm $>$ lime $>$ hornbeam), in the ranking based on the $\mathrm{CP}_{\mathrm{FFB}}$ index ash and lime are ranked somewhat higher, but in general the rankings are similar.

The lowest vertical differentiation (DIFF index) occurred in the neighbourhood of shade-tolerant hornbeams (Fig. 6a). However, insignificantly higher values were also noted in the neighbourhood of light-adapted alder and pine, and the highest rankings were assigned to mid-tolerant species (ash, white elm). Thus, the species ranking suggests no close relation between the light requirements of large-diameter trees and the vertical differentiation in their neighbourhood.

The univariate Ripley's K-function revealed that on small spatial scales (i.e. in the radii below 3-11 $\mathrm{m}$ depending on sample plot), large-diameter trees were regularly distributed

(a) $\mathrm{dbh} \geq 50 \mathrm{~cm}$

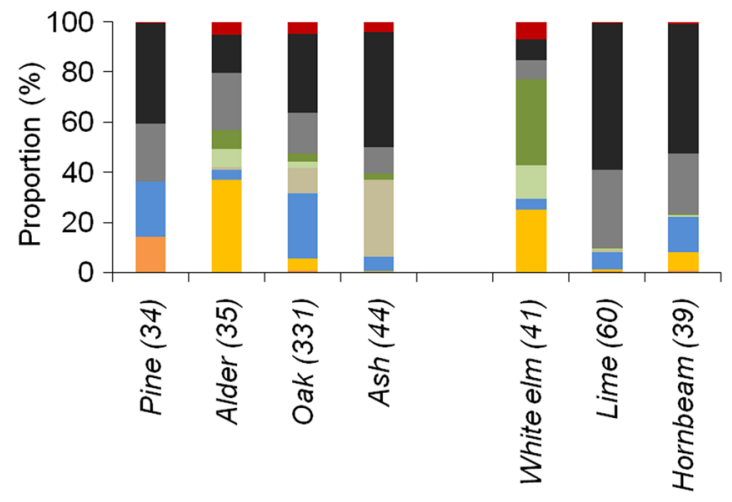

(c) $7 \mathrm{~cm} \leq \mathrm{dbh}<20 \mathrm{~cm}$

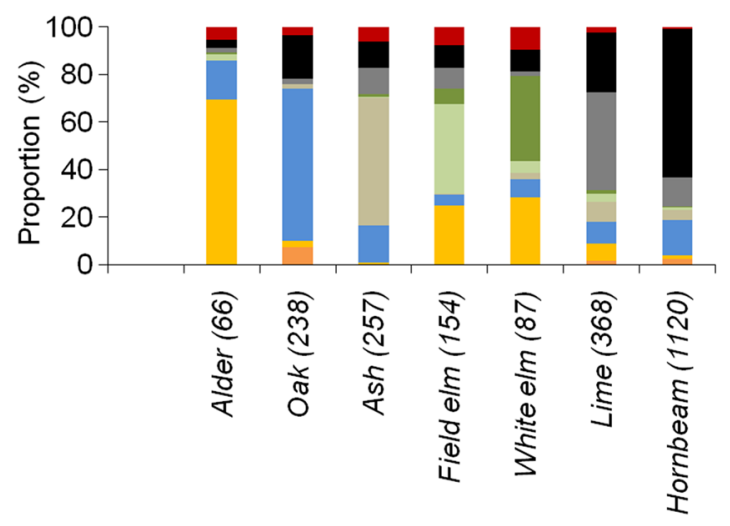

Fig. 1 Species composition in small, circular stand patches corresponding to the projection area of average canopy trees in the neighbourhood of small-, medium-, and large-diameter trees of eight species (with proportions based on stem number). The darker patterns in almost all stands (Table 2), a tendency clearly visible for species with different shade tolerance. The distribution patterns of species with different shade tolerance, in contrast, were frequently negatively dependent (Table 3 ), although in the overwhelming majority of cases, this repulsion was only detectable at small spatial scales for radii below 2-8 $\mathrm{m}$.

\section{Medium-diameter trees}

The proportion of light-adapted trees decreased in the surroundings of shade-tolerant limes and hornbeams (Fig. 1b). Nonetheless, the results suggest that medium-diameter trees of light-adapted species might persist in stand patches with a small proportion of mid-tolerant and/or shade-tolerant species. The highest species diversity was found in the neighbourhood of ash, alder, and white elm and the lowest around oaks, limes, and hornbeams (Fig. 2b).

The analysis did not reveal any significant differences between species shade tolerance and local basal area (Fig. 3b). However, this situation changed when

(b) $20 \mathrm{~cm} \leq \mathrm{dbh}<50 \mathrm{~cm}$

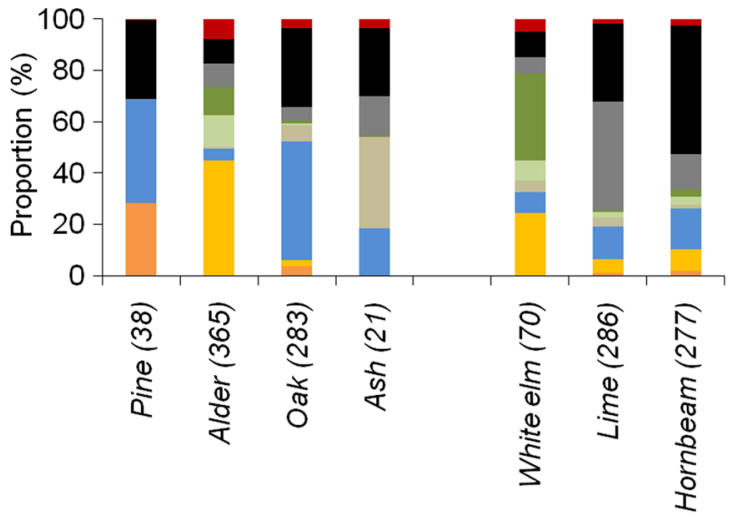

$$
\begin{aligned}
& \text { Others } \\
& \text { Hornbeam } \\
& \text { Wime } \\
& \text { White elm } \\
& \text { Ash elm } \\
& \text { Oak } \\
& \text { Alder }
\end{aligned}
$$

correspond to a higher species shade tolerance. Notes: The numbers in brackets are the number of stand patches analysed. The species are ordered according to increasing shade tolerance 


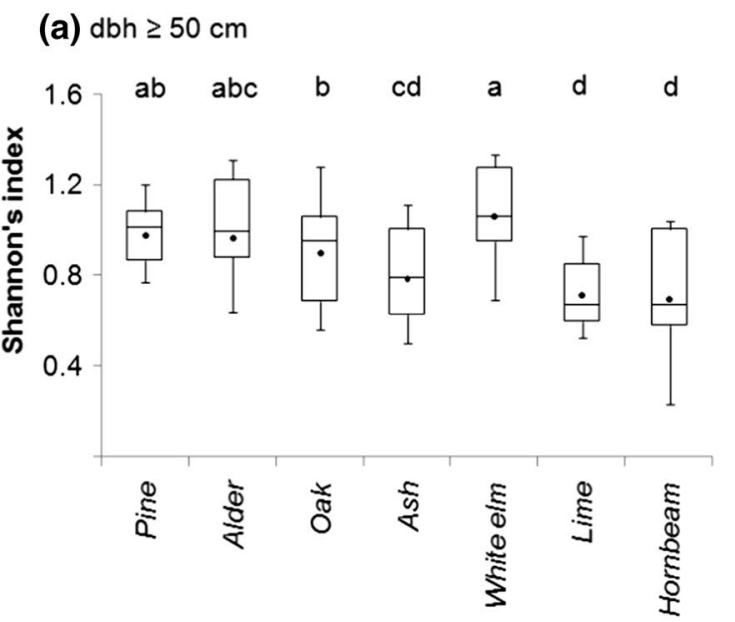
(b) $20 \leq \mathrm{dbh}<50 \mathrm{~cm}$

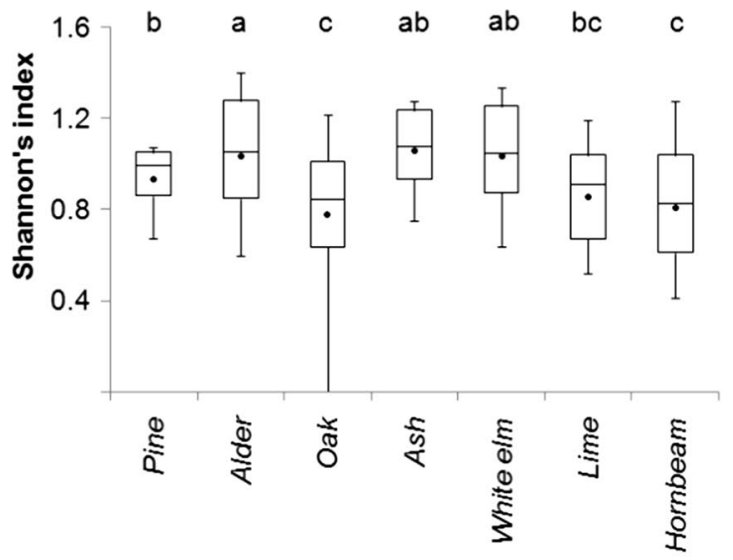

(c) $7 \mathrm{~cm} \leq \mathrm{dbh}<20 \mathrm{~cm}$

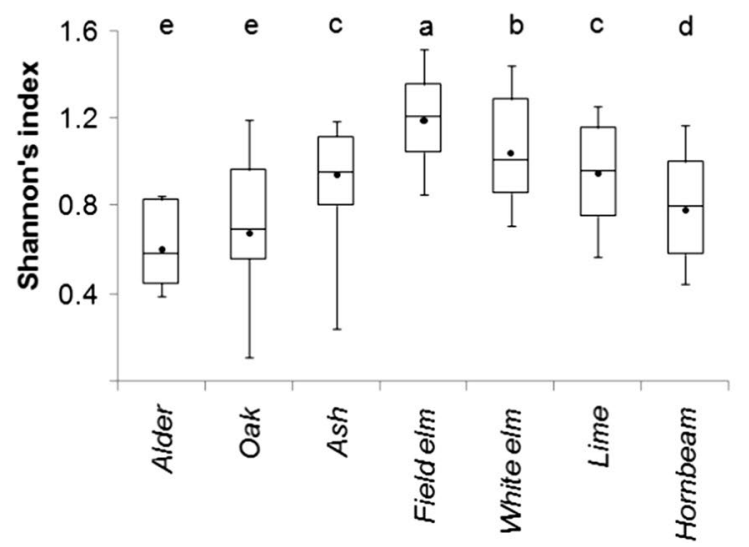

Fig. 2 The Shannon diversity index calculated for small stand patches in the neighbourhood of small-, medium-, and large-diameter trees of eight species (means, medians, quartiles, and 10th and 90th percentiles)

species-specific LAI was taken into account (Fig. 4b). Then, the $\mathrm{BA}_{\mathrm{LAI}}$ values were low for pine, oak, and ash, but higher for white elm, lime, and hornbeam. Thus, except for alder, species sequence closely resembles the ranking of the species-specific light requirements. Small-diameter trees colonized the under-crown zones of medium-diameter shade-tolerant trees less frequently than they did those of light-adapted trees (Fig. 5b). In the case of the $\mathrm{CP}_{\mathrm{FFA}}$ index (i.e. fraction of crown projections free from above), the ranking of the species was similar (Fig. 5c).

Although the differentiation in vertical structure expressed by the DIFF index varied, it was not related to species' light requirements (Fig. 6b), as clearly illustrated by pine and hornbeam, two species with contrasting light requirements for which the index values did not differ significantly. In fact, similar DIFF values were obtained for light-adapted pine, mid-tolerant ash, and shade-tolerant lime and hornbeam.

Independent of shade tolerance, medium-diameter trees frequently exhibited aggregated or regular distribution patterns, with deviations towards regular patterns found most often for radii below $10 \mathrm{~m}$ (Table 2). In stands with species of different shade tolerance, the spatial distributions can be classified as independent, positive-dependent, and negative-dependent for small radii (usually below $6 \mathrm{~m}$ ) (Table 3). Only in two cases was repulsion for larger radii detected, indicating negative dependence of the species. In overwhelming majority of the stands, the distribution patterns of medium and large-diameter trees were negative-dependent or independent (Supplementary material, Table S2).

\section{Small-diameter trees}

Around small-diameter trees a tendency was observed towards an increasing proportion of exemplars of the same species (Fig. 1c), with the lowest Shannon diversity index values obtained for both the light-adapted alder and oak and the shade-tolerant hornbeam (Fig. 2c). As with the 
(a) $\mathrm{dbh} \geq 50 \mathrm{~cm}$

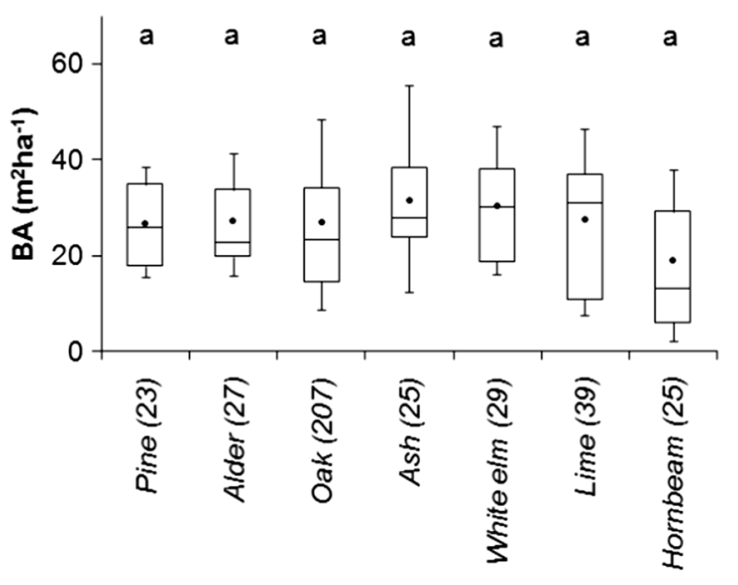

(c) $7 \mathrm{~cm} \leq \mathrm{dbh}<20 \mathrm{~cm}$

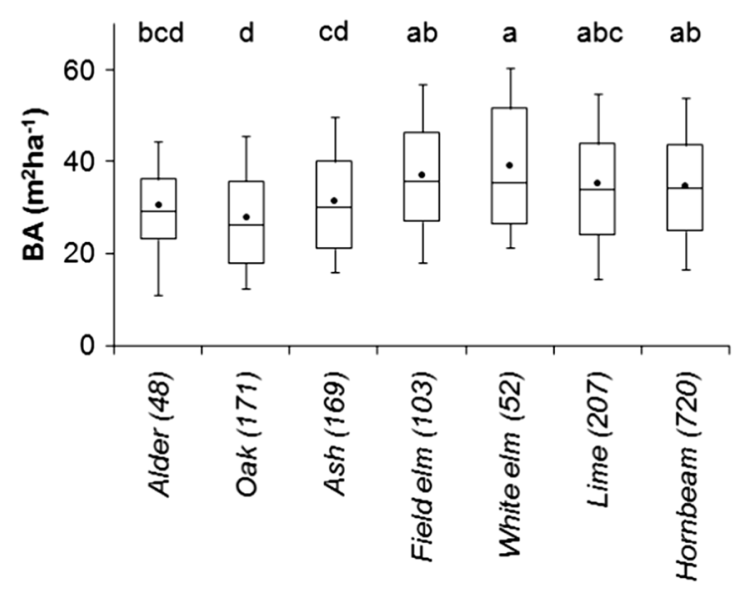

Fig. 3 Local basal area (BA) in the neighbourhood of small-, medium-, and large-diameter trees of eight species (means, medians, quartiles, and 10th and 90th percentiles). Notes: The statistical significance of the between-species differences in index values was tested using two-sided permutation tests (1000 random permutations). For multiple comparisons, a Holm-Bonferroni correction was used with

large and medium-diameter trees, the highest species diversity was found around elms.

Although the local basal area (BA index) was relatively high in the neighbourhood of oak, alder and ash, the average values were lower than around shade-tolerant lime and hornbeam (Fig. 3c). The highest BA values, however, were obtained around mid-tolerant white and field elms. Once species-specific LAI was taken into account, the betweenspecies differences were similar and showed no clear tendency to increase (Fig. 4c). The statistical analysis indicated that except for oak the ranking based on the $\mathrm{CP}_{\mathrm{FFA}}$ index is comparable to the light requirements ranking given in the literature (Fig. 5c).

In agreement with the preliminary hypothesis, the lowest differentiation of vertical structure occurred in the neighbourhood of light-adapted oak (Fig. 6c). Unexpectedly, (b) $20 \mathrm{~cm} \leq \mathrm{dbh}<50 \mathrm{~cm}$

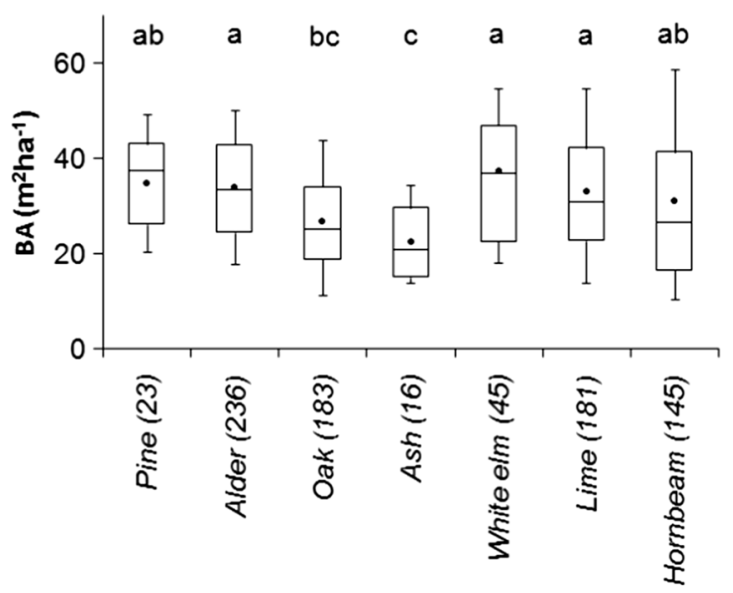

a desired overall alpha level of 0.05 . The same letters indicate species for which no significant differences were found. The numbers in brackets are the number of stand patches analysed. The sample sizes differ from those given for Fig. 1 because the BA index was not calculated for trees growing in the sample plot border zones

however, the next position in the ranking was taken by the most shade-tolerant species, hornbeam, with first position going to the mid-tolerant species white elm and ash. Thus, the differentiation of vertical structure was only weakly correlated with species-specific light requirements.

In almost all stands, small-diameter trees showed aggregated distribution patterns (Table 2), most frequently discernible for a wide range of radii. In fact, the distribution maps reveal dominating patterns in which large clumps of small-diameter trees cover a major part of the sample plots, with gradient changes in their density in some plots. A negative dependence (repulsion) between species with different shade tolerance was detected in only one stand across the entire range of radii analysed (Table 3 ). In overwhelming majority of the stands, the spatial distribution of small- and large-diameter trees was independent or 

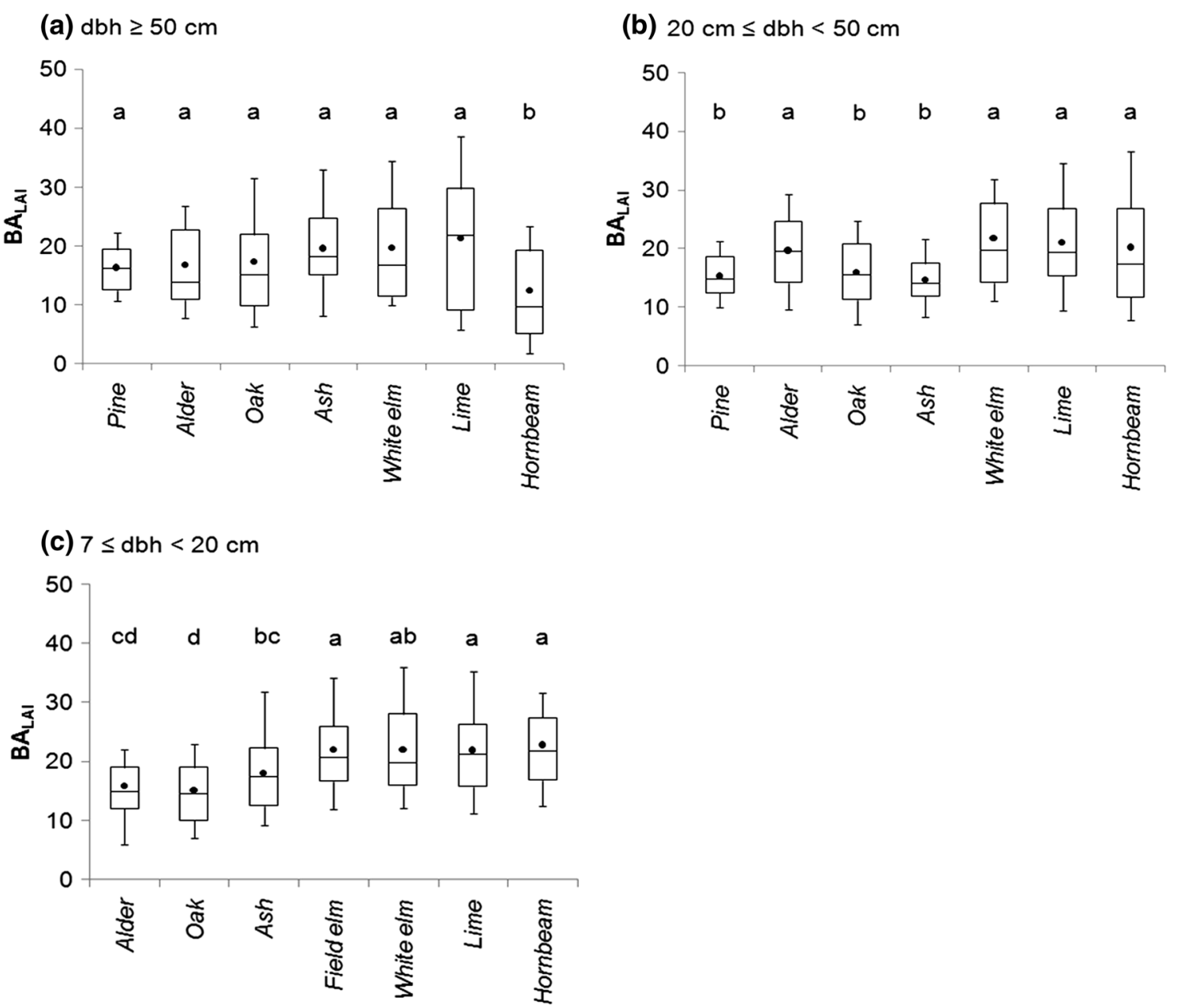

Fig. 4 Local basal area weighted by relative leaf area index of the species $\left(\mathrm{BA}_{\mathrm{LAI}}\right)$ in the neighbourhood of small-, medium-, and large-diameter trees (means, medians, quartiles, and 10th and 90th percentiles). Other details are as for Fig. 3

even positive-dependent and the distributions of small- and medium-diameter trees independent or negative-dependent (Supplementary material Table S2).

\section{Discussion}

\section{Evaluation of the results}

It is generally assumed that in a mixed-species, uneven-aged forest consisting of species with different light requirements, the local differentiation of vertical stand structure reflects successive stages of species' colonization (Connel and Slatyer 1977; Whitmore 1989; Yamamoto 2000). The result is vertical segregation of the species, with younger trees of shade-tolerant species tending to grow underneath the canopy of light-adapted species from the initial succession stages, and a development trajectory that leads to gradual elimination of intolerant, and subsequently also mid-tolerant, species (Faliński 1988; Bobiec 2012; Brzeziecki et al. 2016). The anticipated study outcomes, therefore, were that the increasing light requirements of trees growing in the upper canopy layer would be linked with increasing vertical differentiation in their close neighbourhood (H1) and that the increasing light requirements of small-diameter trees would be negatively correlated with the local structural complexity of the surrounding stand patches (H2). The results, however, indicate only a weak relation between the shade tolerance of canopy trees and local vertical diversification, which effectively disproves H1. Similarly, in the case of small-diameter trees, the ranking of the vertical structure diversification deviates from expectations, giving a sound reason to also reject $\mathrm{H} 2$.

The third assumption (H3) was that more shade-tolerant trees species growing in lower stand layers could endure stronger competition of larger neighbours than less tolerant species and thus would also occur in denser stand patches. In general, our results support this hypothesis because the 
(a) $\mathrm{dbh} \geq 50 \mathrm{~cm}$

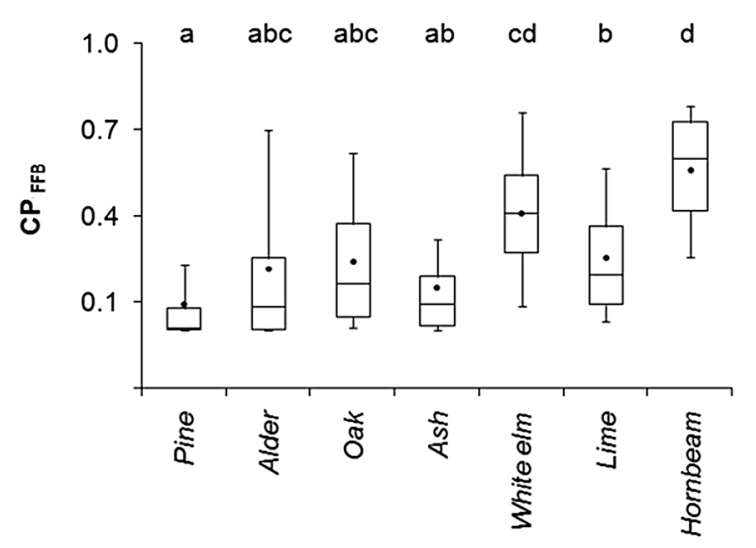

(c) $20 \mathrm{~cm} \leq \mathrm{dbh}<50 \mathrm{~cm}$

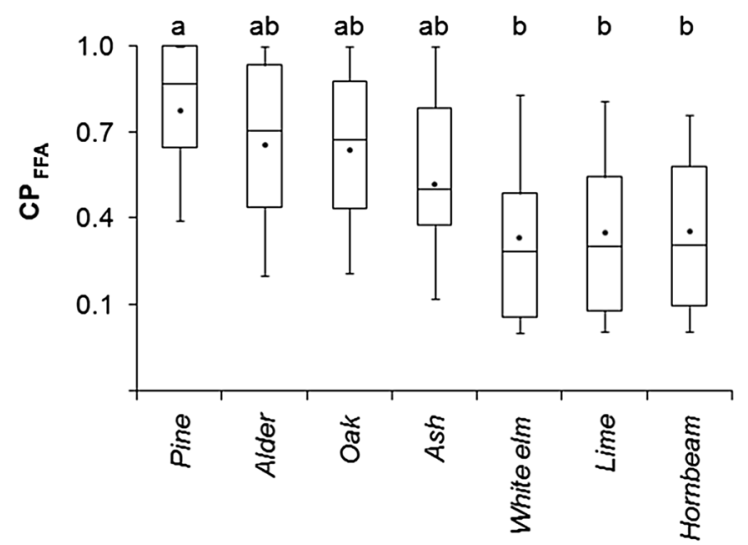

Fig. 5 Relative free crown projection area for medium- and largediameter trees $\left(\mathrm{CP}_{\mathrm{FFB}}\right.$ index, top panel) and for small- and mediumdiameter trees $\left(\mathrm{CP}_{\mathrm{FFA}}\right.$ index, bottom panel). The $\mathrm{CP}_{\mathrm{FFB}}$ index calculations take into account all the neighbouring trees smaller than the

shade-tolerant species growing in lower canopy strata were indeed characterized by a lower proportion of free crown projections $\left(\mathrm{CP}_{\mathrm{FFA}}\right.$ index $)$ and higher values of local basal area corrected for species-specific LAI (BA $\mathrm{BAI}_{\mathrm{LI}}$ index). Nonetheless, it seems remarkable that the differences in local basal area (BA index) between the shade-tolerant (lime, hornbeam) and mid-tolerant species (elms) in the smalldiameter class and between the shade-tolerant and lightadapted species (pine, alder) in the medium-diameter class were non-significant. This outcome suggests that even midtolerant and intolerant species are able to endure the relatively strong competition of neighbouring trees, although, as this analysis has shown, they tend to avoid the close neighbourhood of larger shade-tolerant tree species.

The interspecific spatial segregation as an effect of the niche differentiation or habitat filtering has been frequently reported in the literature (Paluch and Bartkowicz 2004; Stoll and Newbery 2005; Shen et al. 2013; Szmyt and Tarasiuk (b) $20 \mathrm{~cm} \leq \mathrm{dbh}<50 \mathrm{~cm}$

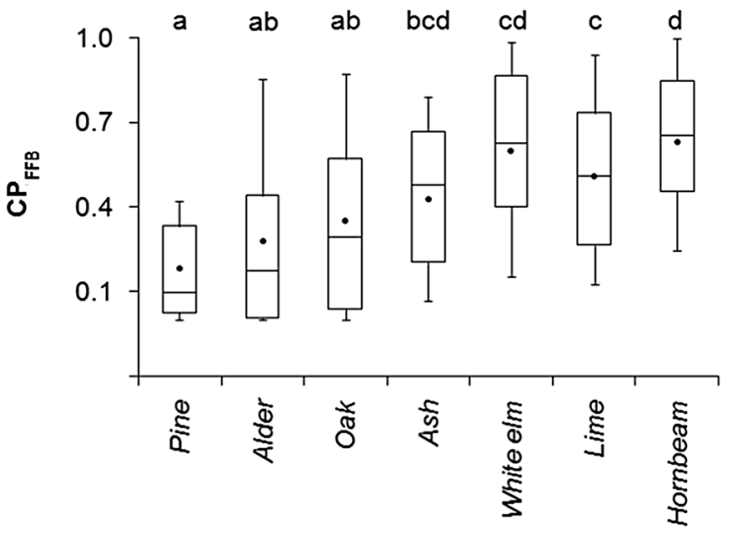

(d) $7 \mathrm{~cm} \leq \mathrm{dbh}<20 \mathrm{~cm}$

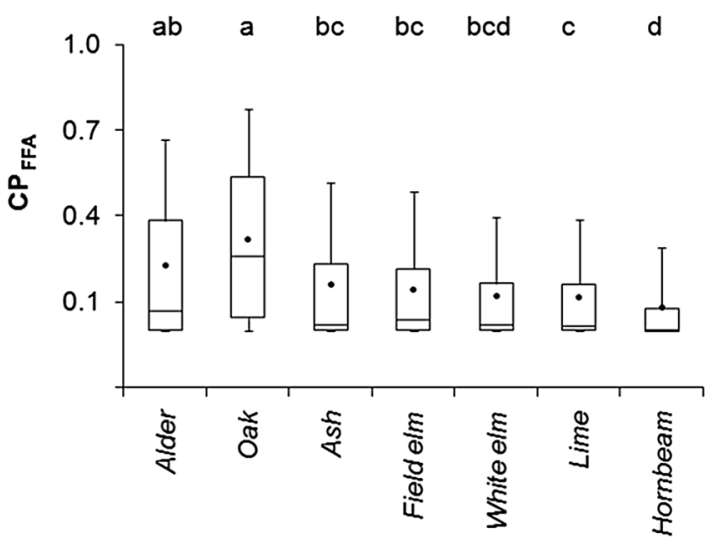

subject tree, whereas the $\mathrm{CP}_{\mathrm{FFA}}$ index calculations are based on all neighbouring trees higher than the subject tree. Notes: The sample sizes are the same as for Fig. 1. Other details are as for Fig. 3

2018). Although our study did not address this issue directly, one factor that potentially controls the spatial segregation in the studied forests is the fine-grained micro-topography, which in association with periodical flooding episodes may locally reduce the competitiveness of hornbeam and lime and favour small-scale mixtures of hygrophilous species like alder, ash, or elm. In fact, in extreme cases, flooding leads to elimination of these shade-tolerant and expansive species (Janik et al. 2011). This effect is clearly visible in Fig. 1, which indicates that the proportion of shade-tolerant lime or hornbeam is lower in the neighbourhood of light-adapted alder, or mid-tolerant ash and elm, than in the neighbourhood of shade-tolerant species. Another factor with a potential to decrease the competitiveness of shade-tolerant hornbeam and lime relative to light-adapted oak and pine is lower site trophism. The results suggest that spatial site variability or silvicultural control over the competitiveness of expansive shade-tolerant species may facilitate the persistence 
(a) $d b h \geq 50 \mathrm{~cm}$

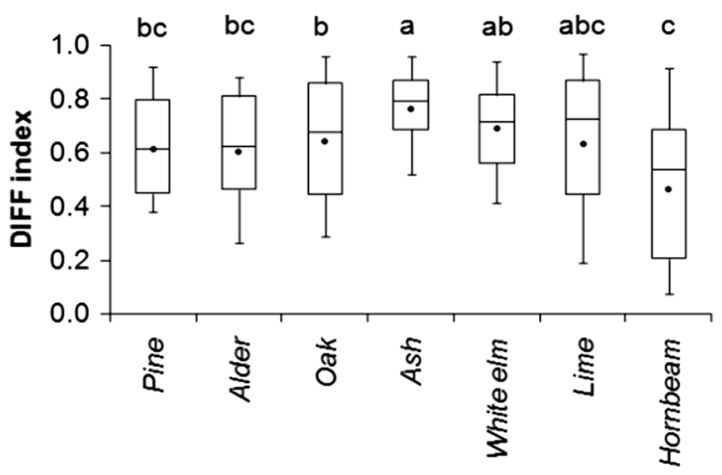

(b) $20 \mathrm{~cm} \leq \mathrm{dbh}<50 \mathrm{~cm}$

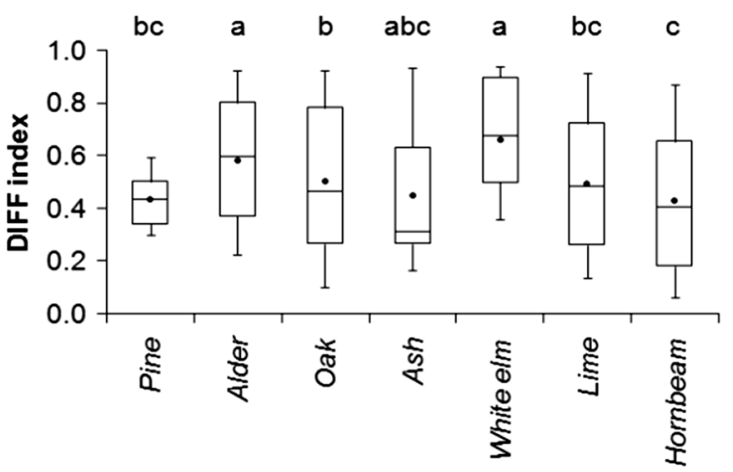

(c) $7 \mathrm{~cm} \leq \mathrm{dbh}<20 \mathrm{~cm}$

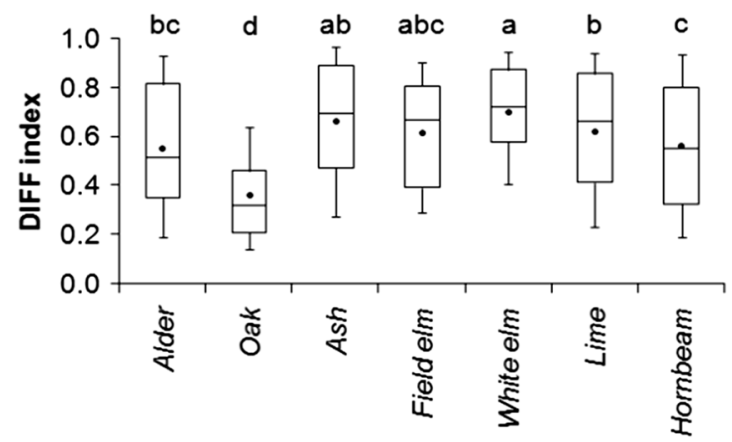

Fig. 6 Index of vertical differentiation (DIFF) in the neighbourhood of small-, medium-, and large-diameter trees of eight species, (means, medians, quartiles, and 10th and 90th percentiles). The sample sizes are the same as for Fig. 1. Other details are as for Fig. 3

of light-adapted and mid-tolerant species in uneven-aged deciduous forests.

Admittedly, the data used for the analyses come from one-time measurement, which reduces the field of interpretation and precludes inferences on dynamic processes such as past growth and perspectives for future advancement of a single species (Schütz 2001). Nevertheless, although less probable given the conservative management methods used in the study region, the stands with different proportions of light-adapted species could have been subjected to different disturbance regimes or management intensity, which would have influenced the heterogeneity of species composition and the present stand structure. Whether or not such is the case, the study results clearly indicate that unevenaged populations of species with different shade tolerance can co-exist for a long time in stands with diverse vertical structure and considerable density. In the case of intolerant and mid-tolerant species, the lack of any evident tendency to grow in stand patches of reduced basal area is even more surprising given that the basal area in the stands studied was relatively high, between 25.6 and $41.4 \mathrm{~m}^{2} \mathrm{ha}^{-1}$. These values exceed those given for deciduous stands under a selection system in the northern hardwood region $\left(11.5-20.7 \mathrm{~m}^{2} \mathrm{ha}^{-1}\right.$, Gronewold et al. 2010), for multi-aged oak stands on xeric sites (16.8 $\mathrm{m}^{2} \mathrm{ha}^{-1}$, Loewenstein et al. 2000), and for beech stands under a selection system in Thuringia (Germany) (about $19 \mathrm{~m}^{2} \mathrm{ha}^{-1}$, Schütz 2001).

Crucial prerequisites for the overgrowing of smaller trees into the upper canopy are sufficient light intensity and the presence of canopy gaps. In the case of small- and mediumdiameter trees, the proportion of free crown projections $\left(\mathrm{CP}_{\mathrm{FFA}}\right.$ index $)$ in the studied stands was relatively small, indicating a need for intensive release treatments to promote these trees and maintain diversified diameter distributions over a longer time period. In fact, both field observations and measurements (data not reported) indicate that the trees of less shade-tolerant species growing in gaps have wellformed tops, crowns, and stems, and could advance into the upper canopy layer. This is because in shaded environments stem forms and their development depend not only on shade tolerance but also on species-specific architecture (Canham 1988; Poulson and Platt 1989; Peltier et al. 1997; Reininger 2000; Emborg 2007). Hence, when less shadetolerant species with a branching system characterized by stronger apical dominance (e.g. alders, ashes, maples, elms) grow in small gaps, they usually maintain fine stem quality. For example, ash forms age-balanced populations not only in forests with oak (Hofmeister et al. 2004) but also under a 
Table 3 Spatial dependence of distribution patterns of trees from different size classes and shade tolerance groups characterized using a bivariate Ripley's K-function

\begin{tabular}{|c|c|c|c|c|c|c|c|c|c|}
\hline \multirow[t]{2}{*}{ Plot no. } & \multicolumn{3}{|c|}{$\begin{array}{l}\text { Large-diameter trees } \\
(d b h \geq 50 \mathrm{~cm})\end{array}$} & \multicolumn{3}{|c|}{$\begin{array}{l}\text { Medium-diameter trees } \\
(20 \mathrm{~cm} \geq d b h<50 \mathrm{~cm})\end{array}$} & \multicolumn{3}{|c|}{$\begin{array}{l}\text { Small-diameter trees } \\
(7 \mathrm{~cm} \geq d b h<20 \mathrm{~cm})\end{array}$} \\
\hline & $\begin{array}{l}\text { Intolerant ver- } \\
\text { sus tolerant }\end{array}$ & $\begin{array}{l}\text { Mid-tolerant } \\
\text { versus toler- } \\
\text { ant }\end{array}$ & $\begin{array}{l}\text { Mid-tolerant } \\
\text { versus intoler- } \\
\text { ant }\end{array}$ & $\begin{array}{l}\text { Intolerant } \\
\text { versus toler- } \\
\text { ant }\end{array}$ & $\begin{array}{l}\text { Mid-tolerant } \\
\text { versus toler- } \\
\text { ant }\end{array}$ & $\begin{array}{l}\text { Mid-tolerant } \\
\text { versus intol- } \\
\text { erant }\end{array}$ & $\begin{array}{l}\text { Intolerant } \\
\text { versus toler- } \\
\text { ant }\end{array}$ & $\begin{array}{l}\text { Mid-tolerant } \\
\text { versus toler- } \\
\text { ant }\end{array}$ & $\begin{array}{l}\text { Mid-tolerant } \\
\text { versus intol- } \\
\text { erant }\end{array}$ \\
\hline 1. & - & - & - & 0 & - & - & $\mathrm{P}>10$ & - & - \\
\hline 2. & $\mathrm{~N}<2$ & - & - & $\mathrm{N}<2 \mathrm{P}>12$ & - & - & - & - & - \\
\hline 3. & $\mathrm{~N}<4 \mathrm{~N}>10$ & - & - & - & - & - & - & - & - \\
\hline 4. & $\mathrm{~N}<6$ & - & - & - & - & - & - & - & - \\
\hline 5. & $\mathrm{~N}<5$ & - & - & - & - & - & - & - & - \\
\hline 6. & 0 & - & - & - & - & - & - & - & - \\
\hline 7. & $\mathrm{~N}<13 \mathrm{~N}>17$ & - & - & $P>5$ & - & - & - & - & - \\
\hline 8. & - & - & - & $\mathrm{N}<4$ & - & - & - & - & - \\
\hline 9. & - & - & - & $\mathrm{P}>7$ & $\mathrm{~N}<4$ & $\mathrm{~N}<2$ & $\mathrm{P}>9$ & 0 & $\mathrm{~N}<4$ \\
\hline 10. & - & - & $\mathrm{N}<6$ & $\mathrm{~N}<2$ & - & - & - & 0 & - \\
\hline 11. & - & - & $\mathrm{N}<4 \mathrm{~N}>7$ & 0 & $\mathrm{~N}<6$ & $\mathrm{~N}<4$ & - & 0 & - \\
\hline 12. & - & - & $\mathrm{N}<10$ & - & - & $\mathrm{N}<5$ & - & - & - \\
\hline 13. & - & - & - & $\mathrm{P}>5$ & - & - & - & $\mathrm{N}<4$ & \\
\hline 14. & - & - & $\mathrm{N}>0$ & $\mathrm{~N}>5$ & 0 & 0 & - & $\mathrm{N}>0$ & - \\
\hline 15. & - & - & $\mathrm{N}<8 \mathrm{~N}>14$ & $8>P<13$ & $\mathrm{~N}<10$ & $\mathrm{~N}>0$ & - & 0 & - \\
\hline 16. & - & - & $\mathrm{N}<3$ & 0 & $\mathrm{~N}<15$ & 0 & - & 0 & - \\
\hline 17. & - & - & $\mathrm{N}<36>\mathrm{N}<12$ & 0 & $\mathrm{~N}<2$ & 0 & - & $\mathrm{P}>8$ & - \\
\hline 18. & - & - & - & - & - & - & $\mathrm{N}<2$ & - & - \\
\hline
\end{tabular}

$\mathrm{P}=$ positive dependence (attraction), $\mathrm{N}=$ negative dependence (repulsion), $0=$ independence. The numbers in brackets indicate spatial ranges (in $\mathrm{m}$ ) of significant deviations towards positive or negative dependence (two-sided $\alpha=0.05$ ). The calculations were performed if the number of trees in a given group exceeded 10 per sample plot. Shade tolerance groups as in Table 2

regime of intensive small-scale disturbances in mixed-species stands with the highly competitive beech (Emborg et al. 2000). Nevertheless, in shaded environments, the growth rates of species with different shade tolerance significantly differ (Craig et al. 2014), and the more shade-tolerant species are likely to be much more competitive (Miścicki 2012; Brzeziecki et al. 2016).

\section{Implications for continuous-cover forestry in deciduous forests}

For light-adapted species, complex vertical structures are difficult to achieve because of their effective regeneration being impeded by competition from forest floor vegetation and herbivorous ungulates (Kuijper et al. 2010; Bobiec 2012) and the reduced growth plasticity of young trees developing in a shaded environment (Schütz 2001). In mixed stands, additional problems arise with expansion of competitive species (Bernadzki et al. 1998; Janik et al. 2008; Brzeziecki et al. 2016; McEwan and Muller 2006; Hart and Grissino-Mayer 2008; Cowell et al. 2010). In the face of these limitations, minimal gap size is crucial to preserving the competitive ability of species such as alder, oak, ash, and-on less fertile sites-also pine.

Dendrochronological studies have revealed that oakdominated stands in the central hardwood region originated under a specific disturbance regime with frequent smallscale disturbances and canopy openings $<200 \mathrm{~m}^{2}$ (Rentch et al. 2003). However, studies from managed stands have indicated that the single-tree selection system caused recession of mid-tolerant species (Schwartz et al. 2005; Keyser and Loftis 2013) suggesting that larger gaps may be needed to maintain mixed-species composition in these forests. Similarly, research on natural regeneration of pedunculate oak in floodplain forests in Slovenia determined the required minimal gap size to be $300-500 \mathrm{~m}^{2}$ (Diaci et al. 2008). On the other hand, in beech forests in Germany, where oaks ( $Q$. robur and $Q$. petraea) are regenerated using silvicultural methods with a permanent canopy, promising results were obtained with gap diameters of about $20 \mathrm{~m}$ (von Lüpke 1998). For the group selection system, Schütz (1992) recommended a gap size of about $400 \mathrm{~m}^{2}$ for deciduous shadetolerant species and $600-900 \mathrm{~m}^{2}$ for mid-tolerant species. Yet light-adapted species frequently fail to gain any significant benefit from gaps larger than 0.3 ha (Malcolm et al. 
2001; Christopher et al. 2005). Thus, employing a range of gap sizes, coupled with the occasional retention of prospective under- and mid-canopy trees growing in clusters or expansion of existing gaps, might have the potential to create highly variable light environments and facilitate greater tree species richness (McClure and Lee 1993; Forrester et al. 2014).

For mixed-species deciduous forests consisting of lightadapted and moderately shade-tolerant species, some authors have proposed silvicultural methods designed to create multi-cohort stands (a patch selection system) with balanced age classes on an area of 20-30 ha (Brzeziecki et al. 2013). In contrast, Larsen et al. (2005) advocated group cuttings for achieving uneven-aged stand structures in mixed-species forests dominated by broadleaved species. Similarly, Saniga (2010) recommended a patch system for beech and oak stands based on shelterwood cuttings carried out successively on small randomly distributed stand patches of 0.2-0.3 ha. Other authors have proposed management of multi-aged late-successional forest based on selection cuttings combined with irregular multi-cohort harvests (Diaci and Firm 2011; Hanson et al. 2012). Such propositions, based on variable harvest regimes, contrast with traditional models of selection forests that emphasize stability and demographic balance and have a greater potential to reconcile tree species' different life strategies while also safeguarding the old-growth attributes of mixed-species forests (O'Hara and Ramage 2013). Nonetheless, several important questions remain unanswered regarding the feasibility of continuous-cover forestry in deciduous forests. The most important are related to the logging damage caused by stand management systems to remaining trees, the growth of suppressed trees and their recovery when more light becomes available, and silvicultural activities aimed at successful regeneration of economically valuable tree species (Hyytiäinen and Haight 2012).

\section{Conclusions}

The results obtained in this study indicate that in the mixedspecies deciduous forests of Central Europe, complex vertical structures arise not only in larger areas of several hundred square metres but also on small spatial scales corresponding to the projection area of canopy trees. They also show that shade-tolerant, mid-tolerant, and light-adapted species may occur in different stand layers and that less shade-tolerant species like pine, alder, ash and oak may endure in relatively small gaps providing that species with similar light requirements prevail in their neighbourhood. Hence, controlling the admixture of shade-tolerant and light-adapted species may be crucial for the persistence of less shade-tolerant species in uneven-aged forests. These results not only suggest that maintaining species diversity in the forest communities studied may not require application of management systems based on extensive canopy openings but more generally call into question the crucial role of intensive disturbances in establishing cohorts of less shade-tolerant species. Nevertheless, further research is needed to explain the mechanisms of species co-existence in uneven-aged deciduous forests, in particular, species-specific growth in reaction to release episodes and the role of microhabitat patchiness in creating small-scale variation in species composition.

Acknowledgements The authors wish to thank two referees for valuable and pertinent comments. This research was financed by the Ministry of Science and Higher Education of the Republic of Poland.

Open Access This article is distributed under the terms of the Creative Commons Attribution 4.0 International License (http://creativeco mmons.org/licenses/by/4.0/), which permits unrestricted use, distribution, and reproduction in any medium, provided you give appropriate credit to the original author(s) and the source, provide a link to the Creative Commons license, and indicate if changes were made.

\section{References}

Andrzejczyk T (2006) Rębnia przerębowa w drzewostanach sosnowych. Sylwan 8:52-60

Andrzejczyk T, Żybura H (2012) Sosna zwyczajna: odnawianie naturalne i alternatywne metody hodowli. Państwowe Wydawnictwo Rolnicze i Leśne, Warszawa, p 278

Angers VA, Messier Ch, Beaudet M, Leduc A (2005) Comparing composition and structure in old-growth and harvested (selection and diameter-limit cuts) northern hardwood stands in Quebec. For Ecol Manag 17:275-293. https://doi.org/10.1016/j.foreco2005 .06 .008

Bachofen H (1999) Gleichgewicht, Struktur und Wachstum in Plenterbeständen. Schweiz Z Forstwes 150:157-170

Bauhus J, Puettmann K, Messier Ch (2009) Silviculture for oldgrowth attributes. For Ecol Manag 258:525-537. https://doi. org/10.1016/j.foreco.2009.01.053

Bernadzki E, Bolibok L, Brzeziecki B, Zajączkowski J, Żybura $\mathrm{H}$ (1998) Compositional dynamics of natural forests in the Białowieża National Park, northeastern Poland. J Veg Sci 9:229_ 238. https://doi.org/10.2307/3237122

Bobiec A (2012) Białowieża primeval forest as a remnant of culturally modified ancient forest. Eur J For Res 131:1269-1285. https://doi. org/10.1007/s10342-012-0597-6

Bobiec A, van der Burgt H, Meijer K, Zuyderduyn C, Haga J, Vlaanderen B (2000) Rich deciduous forests in Białowieża as a dynamic mosaic of developmental phases: premises for nature conservation and restoration management. For Ecol Manag 130:159-175. https ://doi.org/10.1016/S0378-1127(99)00181-4

Bobinac M (2000) Stand structure and natural regeneration of common oak in the nature reserves "Vratična"and "Smogva" near Morović. Glas Šum Pok 37:295-309

Brzeziecki B, Drozdowski S, Bielak K, Buraczyk W, Gawron L (2013) Kształtowanie zróżnicowanej struktury drzewostanów w warunkach nizinnych. Sylwan 157:597-606

Brzeziecki B, Pommerening A, Miścicki S, Drozdowski S, Żybura H (2016) A common lack of demographic equilibrium among tree species in Białowieża National Park (NE Poland): evidence from 
long-term plots. J Veg Sci 27:460-469. https://doi.org/10.1111/ jvs. 12369

Burschel P, Huss J (1997) Grundriss des Waldbaus. Verlag Paul Parey, Hamburg, p 488

Bzowski M (1973) Rzeźba istosunki wodne dna doliny Wisły w rejonie północnej części Puszczy Niepołomickiej. Studia Naturae Seria A 7:7-37

Canham ChD (1988) Growth and canopy architecture of shade-tolerant trees: response to canopy gaps. Ecology 69:786-795

Čermak J (1998) Leaf distribution in large trees and stands of the floodplain forest in southern Moravia. Tree Physiol 18:727-737. https ://doi.org/10.1093/treephys/18.11.727

Christopher R, Webster R, Lorimer CG (2005) Minimum opening sizes for canopy recruitment of midtolerant tree species: a retrospective approach. Ecol Appl 15:1245-1262. https://doi. org/10.1890/04-0763

Connell JH, Slatyer RO (1977) Mechanisms of succession in natural communities and their role in community stability and organization. Am Nat 111:1119-1144

Cowell CM, Hoalst-Pullen N, Jackson MT (2010) The limited role of canopy gaps in the successional dynamics of a mature mixed Quercus forest remnant. J Veg Sci 21:201-212. https://doi.org/1 0.1111/j.1654-1103.2009.01137.x

Craig JM, Lhotka JM, Stringer JW (2014) Evaluating initial responses of natural and underplanted oak reproduction and a shade-tolerant competitor to midstory removal. For Sci 60:1164-1171. https:// doi.org/10.5849/forsci.13-602

Crow TR, Buckley DS, Nauertz EA, Zasada JC (2002) Effects of management on the composition and structure of northern hardwood forests in upper Michigan. For Sci 48:129-145

Diaci J, Firm D (2011) Long-term dynamics of a mixed conifer stand in Slovenia managed with a farmer selection system. For Ecol Manag 262:931-939. https://doi.org/10.1016/j.foreco.2011.05.024

Diaci J, Gyoerek N, Gliha J, Nagel TA (2008) Response of Quercus robur $\mathrm{L}$. seedlings to north-south asymmetry of light within gaps in floodplain forests of Slovenia. Ann For Sci 65:105. https://doi. org/10.1051/forest:2007077

Diggle PJ (1983) Statistical analysis of spatial point patterns. Academic Press, London, p 130

Duguid MC, Ashton MS (2013) A meta-analysis of the effects of forest management for timber on understory plant species diversity in temperate forests. For Ecol Manag 303:81-90. https://doi. org/10.1016/j.foreco.2013.04.009

Dziewolski J (1976) Zarys historii gospodarki leśnej w Puszczy Niepołomickiej. Studia Naturae-Seria A 13:101-106

Efron B, Tibshirani RJ (1993) An introduction to the bootstrap. Chapmann \& Hall/CRC, New York

Eliaš P, Kratochvilova I, Janouš D, Marek M, Masarovičova E (1989) Stand microclimate and physiological activity of tree leaves in an oak-hornbeam forest. Trees 3:227-233

Emborg J (2007) Suppression and release during canopy recruitment in Fagus sylvatica and Fraxinus excelsior, a dendro-ecological study of natural growth patterns and competition. Ecol Bull 52:53-67

Emborg J, Christensen M, Heilman-Clausen J (2000) The structural dynamics of Suserup Skov, a near-natural temperate deciduous forest in Denmark. For Ecol Manag 126:173-189. https://doi. org/10.1016/S0378-1127(99)00094-8

Fahey RT, Lorimer CG (2013) Restoring a midtolerant pine species as a component of late-successional forests: results of gapbased planting trials. For Ecol Manag 292:139-149. https://doi. org/10.1016/j.foreco.2012.12.026

Fahey RT, Lorimer CG (2014) Establishment and persistence of pine populations in late-successional forests: influence of variation in habitat-mediated disturbance regimes. J Veg Sci 25:584-600. https://doi.org/10.1111/jvs.12091
Faliński JB (1988) Succession, regeneration and fluctuation in the Białowieża Forest (NE Poland). Vegetatio 77:115-128. https:// doi.org/10.1007/BF00045757

Forget E, Nolet Ph, Doyon F, Delagrange S, Jardon Y (2007) Ten-year response of northern hardwood stands to commercial selection cutting in southern Quebec, Canada. For Ecol Manag 242:764775. https://doi.org/10.1016/j.foreco/2007.02.010

Forrester JA, Lorimer CG, Dyer JH, Gower ST, Mladenoff DJ (2014) Response of tree regeneration to experimental gap creation and deer herbivory in north temperate forests. For Ecol Manag 329:137-147. https://doi.org/10.1016/j.foreco2014.06.025

Goreaud F, Pélissier R (2003) Avoiding misinterpretation of biotic interactions with the intertype K12-function: population independence vs. random labelling hypotheses. J Veg Sci 14:681-692. https://doi.org/10.1111/j.1654-1103.2003.tb02200.x

Gronewold CA, D'Amato AW, Palik BJ (2010) The influence of cutting cycle and stocking level on the structure and composition of managed old-growth northern hardwoods. For Ecol Manag 259:1151-1160. https://doi.org/10.1016/j.foreco/2010.01.001

Hanson JJ, Lorimer CG, Halpin CR, Palik BJ (2012) Ecological forestry in an uneven-aged, late-successional forest: simulated effects of contrasting treatments on structure and yield. For Ecol Manag 270:94-107. https://doi.org/10.1016/j.foreco.2012.01.017

Hao Zh, Zhang J, Song B, Ye J, Li B (2007) Vertical structure and spatial associations of dominant tree species in an old-growth temperate forest. For Ecol Manag 252:1-11. https://doi.org/10.1016/j. foreco.2007.06.026

Hart JL, Grissino-Mayer HD (2008) Vegetation patterns and dendroecology of a mixed hardwood forest on the Cumberland Plateau: implications for stand development. For Ecol Manag 255:1960 1975. https://doi.org/10.1016/j.foreco.2007.12.018

Hessenmöller D, Bouriaud O, Fritzlar D, Elsenhans AD, Schulze ED (2018) A silvicultural strategy for managing uneven-aged beech-dominated forests in Thuringia, Germany: a new approach to an old problem. Scand J For Res 33:668-680. https://doi. org/10.1080/02827581.2018.1453081

Hofmeister J, Mihaljevič M, Hošek J (2004) The spread of ash (Fraxinus excelsior) in some European oak forests: an effect of nitrogen deposition or successional change? For Ecol Manag 203:35-47. https://doi.org/10.1016/j.foreco.2004.07.069

Hui G, Pommerening A (2014) Analysing tree species and size diversity patterns in multi-species uneven-aged forests of northern China. For Ecol Manag 316:125-138. https://doi.org/10.1016/j. foreco/2013.07.029

Hyytiäinen K, Haight RG (2012) Optimizing continuous cover forest. In: Pukkala T, von Gadow K (eds) Continuous cover forestry. Springer, Dordrecht, pp 195-227. https://doi. org/10.1007/978-94-007-2202-6_6

Ishii HT, Tanabe Sh, Hiura T (2004) Exploring the relationships among canopy structure, stand productivity, and biodiversity of temperate forest ecosystems. For Sci 50:342-355

IUSS Working Group WRB (2015) World Reference Base for Soil Resources 2014, update 2015. International soil classification system for naming soils and creating legends for soil maps. World Soil Resources Reports No. 106. FAO, Rome

Janik D, Adam D, Vrška T, Hort L, Unar P, Kral K, Šamonil P, Horal D (2008) Tree layer dynamics of the Cahnov-Soutok near-natural floodplain forest after 33 years (1973-2006). Eur J For Res 127:337-345. https://doi.org/10.1007/s10342-008-0210-1

Janik D, Adam D, Vrška T, Hort L, Unar P, Kral K, Šamonil P, Horal D (2011) Field maple and hornbeam populations along a 4-m elevation gradient in an alluvial forest. Eur J For Res 130:197-208. https://doi.org/10.1007/s10342-010-0421-0

Jaworski A (2011) Hodowla lasu. Charakterystyka hodowlana drzew i krzewów leśnych. PWRiL, Poznań, p 556 
Keyser TL, Loftis DL (2013) Long-term effects of single-tree selection cutting on structure and composition in upland mixed-hardwood forests of the southern Appalachian Mountains. Forestry 86:255-265. https://doi.org/10.1093/forestry/cps083

Kolström T (1993) Modelling the development of an uneven-aged stand of Picea abies. Scand J For Res 8:373-383. https://doi. org/10.1080/02827589309382784

Kuijper DPJ, Jędrzejewska B, Brzeziecki B, Churski M, Jędrzejewski W, Żybura H (2010) Fluctuating ungulate density shapes tree recruitment in natural stands in Białowieża Primeval Forest. J Veg Sci 21:1082-1098. https://doi.org/10.1111/j.1654-1103.2010.01217.x

Larsen JB, Danish Forest and Nature Agency (2005) Catalogue of forest development types in Denmark (in Danish)

Leak WB (1996) Long-term structural change in uneven-aged northern hardwoods. For Sci 42:160-165

Loewenstein EF, Johnson PS, Garret HE (2000) Age and diameter structure of a managed uneven-aged oak forest. Can J For Res 30:1060 1070. https://doi.org/10.1139/cjfr-30-7-1060

Lorimer CG (1980) Age structure and disturbance history of a southern Appalachian virgin forest. Ecology 61:1169-1184. https://doi. org/10.2307/1936836

Malcolm DC, Mason WL, Clarke GC (2001) The transformation of conifer forests in Great Britain — regeneration, gap size, and silvicultural systems. For Ecol Manag 151:7-23. https://doi.org/10.1016/S0378 $-1127(00) 00692-7$

Matuszkiewicz JM (2001) Zespoły leśne Polski. Wydawnictwo Naukowe PWN, Warszawa, p 358

McClure JW, Lee ThD (1993) Small-scale disturbance in a northern hardwoods forest: effects on tree species abundance and distribution. Can J For Res 23:1347-1360. https://doi.org/10.1139/x93-172

McEwan RW, Muller RN (2006) Spatial and temporal dynamics in canopy dominance of an old-growth central Appalachian forest. Can J For Res 36:1536-1550. https://doi.org/10.1139/x06-046

Miścicki S (2012) Structure and dynamics of temperate lowland natural forest in the Białowieża National Park, Poland. Forestry 85:473-483. https://doi.org/10.1093/forestry/cps044

Nolet PH, Doyon F, Messier CH (2014) A new silvicultural approach to the management of uneven-aged northern hardwoods: frequent low-intensity harvesting. Forestry 87:39-48. https://doi.org/10.1093/ forestry/cpt044

O'Hara KL, Ramage BS (2013) Silviculture in an uncertain world: utilizing multi-aged management systems to integrate disturbance. Forestry 86:401-410. https://doi.org/10.1093/forestry/cpt012

Oliver CD, Larson BC (1996) Forest stand dynamics. Wiley, New York, p 520

Paluch J, Bartkowicz LE (2004) Spatial interactions between Scots pine (Pinus sylvestris L.), common oak (Quercus robur L.) and silver birch (Betula pendula Roth.) as investigated in stratified stands in mesotrophic site conditions. For Ecol Manag 192:229-240. https:// doi.org/10.1016/j.foreco.2004.01.041

Pawlik S (1913) Materyały do historyi leśnictwa w Polsce: Puszcza niepołomska w pierwszej połowie XVIII. wieku. Sylwan 39: 55-73, 110-119, 164-181, 262-273

Peltier A, Touzet M-C, Armengaud C, Ponge J-F (1997) Establishment of Fagus sylvatica and Fraxinus excelsior in an old-growth beech forest. J Veg Sci 8:13-20. https://doi.org/10.2307/3237237

Poulson ThL, Platt WJ (1989) Gap light regimes influence canopy tree diversity. Ecology 70:553-555

Reininger H (2000) Das Plenterprinzip oder die Überführung des Altersklassenwaldes. Leopold Stocker Verlag, Graz, p 238

Rentch JS, Fajvan MA, Hicks RR Jr (2003) Spatial and temporal disturbance characteristics of oak-dominated old-growth stands in the central hardwood forest region. For Sci 49:778-789

Saniga M (2010) Pestovanie lesa. Technická Univerzita vo Zvolene, Lesnická fakulta, Brno, p 221
Saunders MR, Wagner RG (2008) Long-term spatial and structural dynamics in Acadian mixedwood stands managed under various silvicultural systems. Can J For Res 38:498-517. https://doi. org/10.1139/X07-155

Schuler ThM (2004) Fifty years of partial harvesting in a mixed mesophytic forest: composition and productivity. Can J For Res 34:985997. https://doi.org/10.1139/X03-262

Schütz J-Ph (1992) Die waldbaulichen Formen und Grenzen der Plenterung mit Laubbaumarten. Schweiz Z Forstwes 143:442-460. https:// doi.org/10.1093/forestry/75.4.327

Schütz J-Ph (2001) Der Plenterwald und weitere Formen strukturierter und gemischter Wälder. Parey, Berlin, p 207

Schütz J-Ph (2002) Uneven-aged silviculture: tradition and practices. Forestry 75:327-328. https://doi.org/10.1093/forestry/75.4.327

Schütz J-PH (2006) Modelling the demographic sustainability of pure beech plenter forests in Eastern Germany. Ann For Sci 63:93-100. https://doi.org/10.1051/forest:2005101

Schwartz JW, Nagel LM, Webster ChR (2005) Effects of uneven-aged management on diameter distribution and species composition of northern hardwoods in upper Michigan. For Ecol Manag 211:356370. https://doi.org/10.1016/j.foreco/2005.02.054

Schwarz PA, Fahey TJ, Martin CW, Siccama ThG, Bailey A (2001) Structure and composition of three northern hardwood-conifer forests with differing disturbance histories. For Ecol Manag 144:201-212. https://doi.org/10.1016/S0378-1127(00)00371-6

Shen GUS, Fangliang H, Waagepetersen R, Sun IF, Hao Z, Chen ZS, Yu M (2013) Quantifying effects of habitat heterogeneity and other clustering processes on spatial distributions of tree species. Ecology 94:2436-2443

Shugart HH (1984) A theory of forest dynamics. Springer, New York, p 278

Solomon DS, Gove JH (1999) Effects of uneven-age management intensity on structural diversity in two major forest types in New England. For Ecol Manag 114:265-274. https://doi.org/10.1016/S0378 -1127(98)00358-2

Soudani K, Trautmann J, Walter J-MN (2002) Leaf area index and canopy stratification in Scots pine (Pinus sylvestris L.) stands. Int J Rem Sens 23:3605-3618. https://doi.org/10.1080/01431160110110983

Šramek M, Čermak J (2012) The vertical leaf distribution of Ulmus laevis Pall. Trees 26:1781-1792. https://doi.org/10.1007/s0046 8-012-0747-y

Staudhammer ChL, LeMay VM (2001) Introduction and evaluation of possible indices of stand structural diversity. Can J For Res 31:11051115. https://doi.org/10.1139/cjfr-31-7-1105

Stenberg P, Linder S, Smolander H, Flower-Ellis J (1994) Performance of the LAI-2000 plant canopy analyzer in estimating leaf area index of some Scots pine stands. Tree Physiol 14:981-995. https://doi. org/10.1093/treephys/14.7-8-9.981

Stoll P, Newbery DM (2005) Evidence of species-specific neighborhood effects in the Dipterocarpaceae of a Bornean rain forest. Ecology 86:3048-3062. https://doi.org/10.1890/04-1540

Suliński J (1981) Zarys klimatu, rzeźby terenu i stosunki wodne w Puszczy Niepołomickiej. Studia Ośrodka Dokumentacji Fizjograficznej PAN 9:25-69

Szmyt J, Tarasiuk S (2018) Species-specific spatial structure, species coexistence and mortality pattern in natural, uneven-aged Scots pine (Pinus sylvestris L.)-dominated forest. Eur J For Res 137:1-16. https ://doi.org/10.1007/s10342-017-1084-x

von Lüpke B (1998) Silvicultural methods of oak regeneration with special respect to shade tolerant mixed species. For Ecol Manag 106:19-26. https://doi.org/10.1016/S0378-1127(97)00235-1

Whitmore TC (1989) Canopy gaps and the two major groups of forest trees. Ecology 70:536-538. https://doi.org/10.2307/1940195

Yamamoto Sh-I (2000) Forest gap dynamics and tree regeneration. J For Res 5:223-229 